\title{
Editorial: ISSHAC-9 symposium
}

\section{Ninth international symposium, surface heterogeneity effects in adsorption and catalysis on solids, 17-23 July 2015, Wrocław, Poland}

\author{
Władek Rudziński ${ }^{1}$
}

Published online: 16 January 2016

(C) The Author(s) 2016. This article is published with open access at Springerlink.com

The enormous geometric complexity of real solid adsorbents creates a large variety of energetic domains for adsorption on solids. We have called it the surface heterogeneity effects in adsorption and catalysis on solids. To share and broaden the rapidly growing interest in the phenomena involved we have organized a series of symposia devoted specially to the influence of surface heterogeneity on adsorption and catalysis.

That first symposium was held in Kazimierz Dolny in Poland, exactly 23 years ago in July 1992. Several dozen of scientists and their accompanying persons assembled at that first symposium. The success of the first symposium encouraged us to organize next ones every third year.

When organizing that first event, and subsequent symposia, we followed the principle that each symposium should be located in a different but attractive place. In doing this, we have followed the timeless Roman dictum that "spirit of place is crucial to the success of an enterprise". This time we organized it in Wrocław. At various times of its rich history, Wrocław has been part of the Kingdom of Poland, Bohemia, Hungary, the Austrian Empire, Prussia and Germany. It became part of Poland in 1945 as a result of the border changes after the Second World War.

Dr. Wladek Rudzinski is ISSHAC-9 Chair and Guest Editor of the Special Issue of Adsorption.

\section{Władek Rudziński}

Wladyslaw.Rudzinski@umcs.lublin.pl

1 Department of Theoretical Chemistry, Faculty of Chemistry, Maria Curie-Skłodowska University, pl. Maria CurieSklodowskiej 3, 20-031 Lublin, Poland

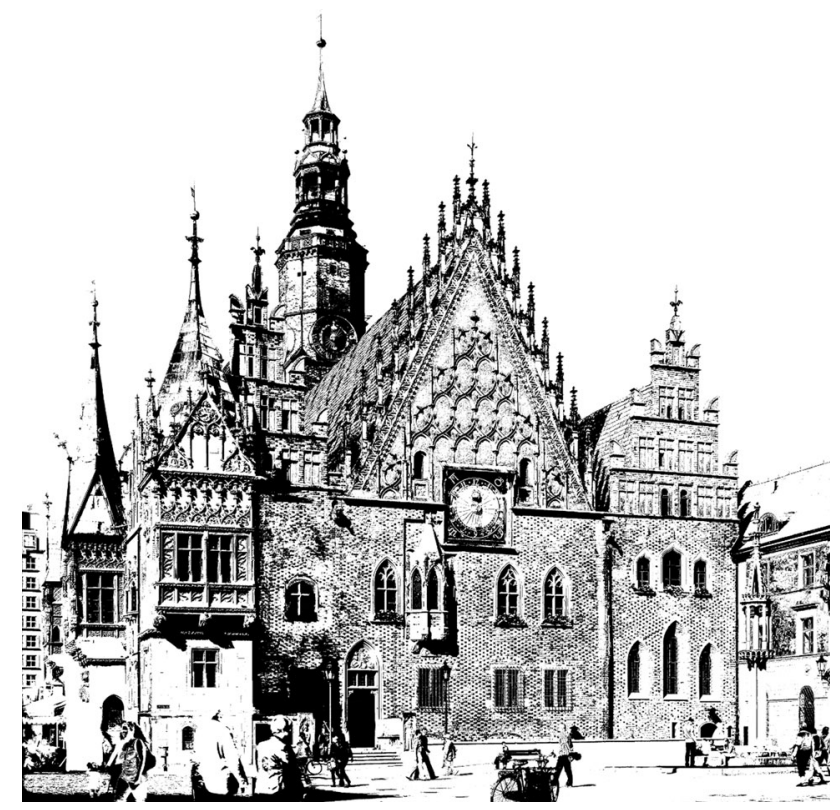

For its rich European history Wrocław has been nominated the European Capital of Culture in 2016. That unique spirit of this historical city made our present symposium a great scientific success and unforgettable social experience.

135 active participants and accompanying persons attended ISSHAC-9 Symposium. There were 61 oral and 84 poster presentations.

Open Access This article is distributed under the terms of the Creative Commons Attribution 4.0 International License (http://crea tivecommons.org/licenses/by/4.0/), which permits unrestricted use, distribution, and reproduction in any medium, provided you give appropriate credit to the original author(s) and the source, provide a link to the Creative Commons license, and indicate if changes were made. 